Lepr Rev (1988) 59, 231-234

\title{
Leprosy in Turkey
}

\author{
A H AYTEKIN* \& T SAYLAN $\dagger$ \\ * Uludağ University Medical School, Department of Community \\ Health Bursa, Turkey; †Istanbul University Medical School, \\ Department of Dermatology, Istanbul, Turkey
}

\section{Accepted for publication 4 November 1987}

\begin{abstract}
Summary An account is given of the historical development of leprosy work and control measures in Turkey. Detailed information is recorded on the distribution of the disease according to year of registration; age; sex; classification. After thorough examination of the patient registers and other sources of information, it can now be confidently stated that reliable data exist for a total of 3851 leprosy patients in Turkey. Studies of distribution of cases in the provinces and regions reveal some curious discrepancies between areas of high and low prevalance, not explained by socio-economic or other factors. The systematic examination of registers and other records, as described in this article, may be of value in other countries, especially when the incidence rate is decreasing, in defining the overall problem and maintaining the interest of health authorities and personnel.
\end{abstract}

\section{Introduction and Historical background}

For thousands of years many tribes and nations have passed through or settled in Anatolia. Among them the first who recognized leprosy were probably the Hittites. They established the city of Paflagonia (Kastamonu) and built a leprosarium. ${ }^{1}$ In the following centuries, with migrations from Palestine and the Middle East, leprosy became established in Anatolia and during the rule of the East Roman Empire (Byzantium) it became endemic. Byzantium built 5 leprosaria in Constantinopolis (Istanbul) alone. During the rule of the Ottoman Empire the situation did not change very much and the new rulers of Anatolia built leprosaria in many cities. Leprosy patients who lived in these centres received enormous aid from local people. According to Zambacho Pasha, during the last decades of the Ottoman Empire, there were 600,000 or more leprosy patients in the whole country. ${ }^{1,2}$

Within the first years of the Republic (mid 1920s) the patients in the leprosaria of Istanbul were taken to a special leprosy hospital in Bakirköy. In 1941 a new leprosy hospital was also built for Eastern Anatolia, in the city of Elazig. ${ }^{1}$

In Turkey, the fight against leprosy began in the early 1960s. The Ministry of Health and Social Assistance (SSYB) etablished a study group with the help of the World Health Organization (WHO) and this group discovered many new patients, especially in Eastern and South Eastern Anatolia. ${ }^{2}$ We can see the distribution of leprosy patients according to the year of registration in Table 1 . 
Table 1. The distribution of leprosy patients in Turkey, according to the year of registration $^{1}$

\begin{tabular}{|c|c|c|c|c|c|}
\hline \multirow{2}{*}{$\begin{array}{l}\text { Registration } \\
\text { years }\end{array}$} & \multirow{2}{*}{$\begin{array}{l}\text { No. of } \\
\text { registered } \\
\text { cases }\end{array}$} & \multicolumn{3}{|c|}{$\begin{array}{l}\text { Patients today } \\
\text { on registration }\end{array}$} & \multirow{2}{*}{$\begin{array}{c}\text { The rate of registered } \\
\text { patients who are } \\
\text { alive today }(\%)\end{array}$} \\
\hline & & Female & Male & Total & \\
\hline$\leqslant 1960$ & $2530^{*}$ & 124 & 250 & 374 & - \\
\hline $1961-70$ & 6295 & 718 & 1364 & 2082 & $33 \cdot 1$ \\
\hline $1971-80$ & 1197 & 244 & 410 & 654 & $54 \cdot 6$ \\
\hline $1981 \leqslant$ & 320 & 102 & 190 & 292 & $91 \cdot 3$ \\
\hline Unknown & - & 153 & 296 & 449 & - \\
\hline Total & 10342 & 1341 & 2510 & 3851 & $37 \cdot 2$ \\
\hline
\end{tabular}

*This figure is not reliable.

During these years studies aimed at finding new cases of leprosy have been performed both widely, as mass screening and, as in local dispensaries. In the following years mass screening has been abandoned, and the duty has been left totally to the local health units which cover a very limited population with the responsibility for polyvalent health care. ${ }^{3}$ Provincial health authorities supervise and support them.

\section{Information about leprosy patients}

Information was compiled first in 1984 by sending a questionnaire to all Provincial Health Directories (67 provinces). This way was chosen because leprosy records are compiled at provincial level and a copy sent to the Ministry of Health. In the mean time other archives that included information about leprosy prevalence rates were also consulted. ${ }^{4}$ This primary information was loaded onto a computer and it was found that Turkey had 4155 registered leprosy cases by the end of 1984. However, when we checked these registered cases we found several mistakes, especially double or multiple registrations. During 1985 we wrote to the provinces and the Ministry of Health and tried to exclude multiple registrations and dead cases.

Today in Turkey all the registered patients have been meticulously scrutinized and their lists are prepared and sent to leprosy hospitals. With the help of the new registration lists it is now possible to find out whether a patient has been previously registered or not. These corrected results were loaded again onto the computer which revealed that there were 3851 registered cases at the beginning of 1986. The distribution of these cases according to sex and age are shown in Table 2.

Mean age of registered female cases is $49 \pm 13 \cdot 5$ (1 SD), male cases $47 \pm 14$ (1 SD). Percentage of females is $34 \cdot 8$, males $65 \cdot 2$. The age of patients when they were first registered was also determined when possible. With the registrations material available today it was impossible to find reliable data on all cases $(10,342)$ that registered until the beginning of 1986 . Reliable data has thus been collected on 3851 cases but we are constantly trying to verify certain details. It has to be acknowledged that two thirds of the cases registered before 1980 are not in registration books today because they had died, were out of control or for other reasons.

With regard to age, we can consider the patients who were registered in 1981 and in the successive 5 years. About $91 \%$ of them are in registration books today and their mean age when they are first registered are $35 \cdot 5 \pm 15 \cdot 4$ ( $1 \mathrm{SD}$ ). Distribution of leprosy cases according to the sex and clinical forms is shown in Table 3.

When we look caref ully at Table 3 we can see that the general ratio of $1 / 1.87$ between the sexes is 
Table 2. The distribution of registered cases, according to age and sex

\begin{tabular}{|c|c|c|c|c|}
\hline \multirow{2}{*}{$\begin{array}{l}\text { Age } \\
\text { groups }\end{array}$} & \multicolumn{2}{|c|}{ Sex } & \multicolumn{2}{|c|}{ Total } \\
\hline & Female & male & No. & $\%$ \\
\hline$\leqslant 14$ & 4 & 13 & 17 & 0.4 \\
\hline $15-44$ & 439 & 919 & 1358 & $35 \cdot 3$ \\
\hline $45 \leqslant$ & 864 & 1513 & 2377 & $61 \cdot 7$ \\
\hline Unknown & 34 & 65 & 99 & $2 \cdot 6$ \\
\hline Total no. & 1341 & 2510 & 3851 & $100 \cdot 0$ \\
\hline$\%$ & $34 \cdot 8$ & $65 \cdot 2$ & $100 \cdot 0$ & \\
\hline
\end{tabular}

Table 3. Distribution of registered cases in Turkey, according to clinical form and sex

\begin{tabular}{lrrrc}
\hline & \multicolumn{2}{c}{ Sex } & & Distribution \\
\cline { 2 - 3 } Clinical forms & Female & Male & Total & $(\%)$ \\
\hline Indeterminate & 111 & 254 & 365 & $9 \cdot 5$ \\
Tuberculoid & 383 & 625 & 1008 & $26 \cdot 2$ \\
Borderline & 56 & 97 & 153 & $4 \cdot 0$ \\
Lepromatous & 752 & 1447 & 2199 & $57 \cdot 1$ \\
Others* & 6 & 17 & 23 & $0 \cdot 6$ \\
Unknown & 33 & 70 & 103 & $2 \cdot 6$ \\
\hline Total & 1341 & 2510 & 3851 & $100 \cdot 0$ \\
\hline
\end{tabular}

* These clinical classifications are obsolete today. But as all patients are not seen again a new classification is impossible. $\left(x^{2}=9 \cdot 36, d f=5, p>0.05\right)$.

consistent when we consider the distribution of clinical forms also. The difference of distribution of clinical forms between female and male groups is not statistically significant.

Today, only $61.5 \%$ of registered cases are under surveillance. Observation data on the rest of the cases are insufficient. There is no important surveillance difference between female and male groups $\left(x^{2}=1 \cdot 55, d f=1, p>0 \cdot 05\right)$.

Most surveyed leprosy cases are of tuberculoid form (70.3\%), with lepromatous cases following them $(62.2 \%)$. Statistical difference between these two clinical forms are significant $\left(x^{2}=20 \cdot 44\right.$, $d f=1, p<0 \cdot 001)$.

With the advancing age of patients, losses are increasing and surveillance rates are decreasing. Young and adult patients have a higher internal migration rate when compared to older patients. Data on age at detection are not significantly different between tuberculoid and lepromatous patients.

\section{Distribution of patients in Turkey}

When we take population figures of Turkey in recent years the prevalence rate of leprosy for 
registered cases is $0 \cdot 07$ per thousand. In the past the highest leprosy prevalence for Turkey was $0 \cdot 1$ per thousand. Especially after 1965 the figures began to decrease towards today's level. The distribution of leprosy in the country also shows some peculiarities. Since the first surveys, Eastern and South-Eastern parts of Anatolia are focal points. In Van, Tunceli and Agri provinces of these regions, the prevalence rate is about 10 times $(0.7$ per thousand) higher than Turkey's mean figure. Some provinces of Eastern Anatolia are following these provinces which have the highest ratio. In Western Anatolia, Bilecik, Zonguldak and Af yon there is a prevalence rate which is about twice as high as Turkey's mean value. In the provinces which have high prevalence rates, some regions have a very high number of cases and neighbouring villages or regions have a very low ratio. For example, in the North Eastern part of Van province, Çaldıran region has a high number of cases, which exceeds the provincial prevalance rate, and in a neighbouring region, which carries similar natural and social conditions, we detected a very low number of cases.

The provinces which have a high prevalence rate in Western Anatolia, have been surveyed caref ully by our study group, and it has been confirmed that this high prevalance rate is true. In these regions of Western Anatolia, a few regions or groups of villages are focal points of disease, and the rest of the province is free of leprosy.

\section{Conclusion}

It is difficult to say that all leprosy patients were registered in the years 1961-65 when mass screening activities were undertaken in Turkey. However, these activities produced reliable information about the regions with higher prevalance rates. As a matter of fact, during the last two decades it has been found that most of the self-reported patients were indeed living in these regions.

For the control of leprosy in other countries it might also be useful to review and analyse old registration lists, especially when leprosy incidence rates have been decreasing, general health conditions are becoming better and health institutions are organized to deal with leprosy control as well.

To analyse old registration lists, qualitatively and quantitatively, it may help to undertake regional studies by choosing small population samples. Such studies will help to define the profile of the disease in the country and will maintain the enthusiasm of health personnel and health authorities in pursuing the goal of eradication.

\section{References}

1 Utku E. Lepra ve Modern Anlamı. Ankara, San Matbaası, 1961.

2 SSYB. Health Statistics Yearbook of Turkey 1961-83. Ankara, SSYB publ.

3 Saylan T. Aytekin AH. Mass screening in leprosy endemic areas of Turkey, preliminary report. Lepr Rev, 1986; 57, 243-9.

4 Taspınar A. et al. Lepralı olguların son 4 yılda yaş grupları ve cinslere göre gösterdiği değişiklikler Lepra Mecmuas1, 1980; 11:4, Ankara. 